\title{
Martin Luther en teologiebeoefening in die toekoms
}

Author:
I.W.C. (Natie) van Wyk'
Affiliation:
'Reformed Theological
College, Faculty of Theology,
University of Pretoria,
South Africa
Correspondence to:
Natie van Wyk
Email:
aim1@mweb.co.za
Postal address:
Private Bag X20, Hatfield
0028, University of Pretoria,
South Africa
Dates:
Received: 04 June 2015
Accepted: 12 July 2015
Published: 28 Sept. 2015
How to cite this article:
Van Wyk, I.W.C., 2015,
'Martin Luther en
teologiebeoefening in die
toekoms', HTS Teologiese
Studies/Theological Studies
71(3), Art. \#3070, 8 pages.
http://dx.doi.org/10.4102/
hts.v71i3.3070
Copyright:
@ 2015. The Authors.
Licensee: AOSIS
OpenJournals. This work is
licensed under the Creative
Commons Attribution
License.

\section{Read online:}

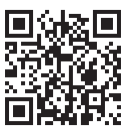

Scan this QR code with your smart phone or mobile device to read online.
Martin Luther and doing theology in the future. The Netherdutch Reformed Church of Africa prides itself for the fact that she has always appreciated the German-Lutheran tradition. The Reformed Theological College has for 15 years contributed to the appreciation of this tradition. This article wants to encourage the new leadership to keep this legacy alive. The main aspects of Luther's theology are explained. These aspects are: prayer (oratio), meditation (meditatio), constitation (tentatio), grace of the Spirit (gratia Spiritus), exegesis (sedulalectio), and the use of other sciences in understanding the Bible (bonarum atrium cognitia). Attention is also given to the subject-matter of Theology as well as the notion of humbleness.

Die Nederduitsch Hervormde Kerk van Afrika (NHKA) kon vir 'n eeu Teologie aan die Universiteit van Pretoria (UP) beoefen. Honderde predikante het ' $n$ goeie akademiese opleiding ontvang wat bygedra het tot die beeld van die NHKA as 'n kerk wat op 'n intellektuele wyse met die evangelie omgaan. Vir die laaste 15 jaar het die Hervormde Teologiese Kollege (HTK) ook 'n belangrike bydrae gelewer om die toekomstige predikante van die NHKA binne die intellektuele kontoere van die reformatoriese teologie te onderrig. In die NHKA is die reformatoriese tradisie nog altyd breër verstaan as eng Calvinisme. Die Duits-Lutherse teologie het nog altyd deel van die NHKA se teologiese benadering gevorm. My indruk is egter dat Luther nie meer die aandag geniet wat hy moet nie. Aangesien daar tans oor die groter rol besin word wat die HTK in die toekoms moet speel, en aangesien ons vinnig op pad is na die 500-jarige herdenking van die Reformasie, is dit nou geleë om Luther opnuut bekend te stel, met die vertroue dat hy in die toekoms die aandag sal geniet wat hy verdien. Een van die redes waarom Luther-navorsing vir die HTK van belang is, hou verband met Luther se aaneenknoping van godsdienstige belangstelling, teologiese kompetensie en kerklike praktyk (Korsch 2010a:92). Ek vertrou dat hierdie verbande in die daarstelling van sy teologie duidelik sal blyk.

Ek dra hierdie artikel op aan my vriend dr Christo van der Merwe. Hy en sy vrou, Rita, het 'n reuse bydrae tot die werksaamhede van die Afrika Instituut vir Missiologie gelewer. Ek is aan hulle groot dank verskuldig.

\section{Martin Luther $\left(1483^{1}-1546\right)$}

Martin Luder, ${ }^{2}$ of Luther, ${ }^{3}$ word algemeen as die vader van die reformatoriese teologie erken. Dit is nie moontlik om aan die volle spektrum van Luther se teologie aandag te gee nie. Sy versamelde werke, bekend en beskikbaar as Werke: Kritische Gesamtausgabe (Weimarer Ausgabe$W A$ ), beloof om ná afhandeling van die redaksionele proses, 125 volumes te beslaan (vgl. Beyer 2010). In die lig van die geweldige omvang van sy geskrifte, kan daar slegs op sekere aspekte van sy teologie gekonsentreer word wat vir die Hervormde Kerk (en ander reformatoriese kerke) op hierdie stadium belangrik mag wees. Selfs uiters belangrike aspekte van sy teologie, soos sy

1.Dit is onseker wat Martin Luther se geboortejaar is. Volgens (vermoedelik) sy eie weergawe (WA TR 5, 5362) is hy op 10 November 1484 in Mansfeld gebore. Volgens sy eerste biograaf, Philipp Melanchthon, is hy egter in 1483 gebore. Die teologiese tradisie volg die 1484 in Mansfeld gebore. Volgens sy eerste biograaf, Philipp Melanchthon, is hy egter in 1483 gebore. Die teologiese tradisie volg die November gedoop en sterf op 18 Februarie 1546 in die ouderdom van 63 jaar. Hy is op 22 Februarie in die 'SchloBkirche' [kasteelkerk] in Wittenberg begrawe.

2.Martin Luder was die seun van Hans en Margarete Luder van Eisleben, Duitsland. In 1484 verhuis die familie na Mansfeld en in 1488 begin hy dáár met sy Latynse skoolonderrig. In 1497 wissel hy na die skool van die 'Brüdern vom gemeinsamen Leben' [broeders van die gemeenskaplike lewe] in Magdeburg. Een jaar later, in 1498, besoek hy die 'Pfarrschule' [predikante skool] van St. Georgen in Eisenach. In 1501 begin hy met sy studie aan die Universiteit van Erfurt (dieselfde jaar waarin die Universiteit van Wittenberg gestig is). In Januarie 1505 promoveer hy tot Magister Artium en in Mei begin hy met regstudie, maar beleef op 02 Julie die strormbelewenis te Stotternheim. Hy belowe om 'n monnik te word. Op 17 Julie neem hy sy intrek in die Augustynse klooster te Erfurt. In 1506 lê hy sy te Stotternheim. Hy belowe om $n$ monnik te word. Op 17 Julie neem hy sy intrek in die Augustynse klooster te Erfurt. In 1506 lê hy sy beloftes af en word op 03 April 1507 as priester gewy. Hy begin met sy teologiese studie en raak bevriend met Johannes von Staupitz. In 1508 beroep Staupitz Luther na Wittenberg om Moraalfilosofie te doseer. In Maart 1509 behaal hy ' $n$ Baccalaureus in Teologie en keer tydelik na Erfurt terug. Nadat hy vir 'n jaar in Rome was, keer hy in 1511 na Wittenberg terug as onderhoof van die Augustyne Klooster en dosent in Teologie. Op 19 November 1512 promoveer hy tot doktor in die Teologie en begin met sy voorlesings vgl. Zschoch 2010a vir 'n bondige oorsig oor sy lewensgang. Vir die nuutste biografieë kyk na Leppin 2010, Schilling 2014 en Schwarz [1986] 2014).

3.Op 31 Oktober 1517 skryf Martin Luder ' $n$ brief aan Aartsbiskop Albrecht van Mainz. Vir die eerste keer onderteken hy die brief as Martin Luther. Hierdie naamsverandering simboliseer sy nuwe selfverstaan. Hy is nou vry. Sy nuutgevonde evangeliese vryheid bring hom daartoe om sy benaming met 'Eleutherius' uit te brei. Van hier af heet hy Frater Martinus Eleutherius Luther - verteenwoordiger van die vryheid van die evangelie (vgl. Schilling 2010:101 en Zschoch 2010a:82). 
Christologie (vgl. Slenczka 2010) en die tema van vryheid, wat dalk die tematiese hart van sy teologie is (vgl. Kettunen 2012) kan weens die beperkte ruimte nie hier aandag geniet nie. Nie-Luther-spesialiste wat in 'n breedvoeriger oorsig belangstel, kan Bayer (1994:35-126, 1995, 2001, 2003), Lohse (1995) en Schwarz [1986] 2014 lees.

\section{Wie beoefen teologie?}

Indien Luther 'n sistematiese handboek geskryf het, sou hy nie met die vraag 'Wat is teologie?' begin het nie. Hy sou eerder gevra het 'Wie is 'n teoloog?' (Bayer 1995). Volgens Luther is alle gelowiges teoloë. Op 17 Januarie 1535, sê hy (WA 41, 11, 9-13) in 'n preek na aanleiding van Psalm 5:17: 'Omnes dicimur Theologi, ut omnes Christiani' [Ons is almal teoloë, soos ons almal ook Christene is]. ${ }^{4}$ Gelowiges word teoloë aangesien die Christelike geloof mense uitnooi om te dink. Gelowiges dink oor die vraag, 'wie is ek, of ons?', in die lig van die feit dat God met ons bemoeienis maak in die wet en die evangelie. Nadenke oor die wonder dat God met my praat, lei daartoe dat ek in gebed, in lof en 'n klaaglied, in dank, aanbidding en voorbidding reageer - en minstens dít is die hoekstene van teologie, naamlik 'n gelowige nadenke oor God in Christus.

Gelowiges wat teologie beoefen is mense wat hulle deur die wet en die evangelie in die prediking laat beïnvloed, en hoor en luister wat gesê word. In 1517/1518 skryf Luther (WA 57, $3,222,7)$ na aanleiding van Hebreërs 10:5: 'Schema Jisrael Hoor!' (Deut 6: 4) - '('Solae aures sunt organa Christiani hominis' [Alleen die ore is die organe van 'n Christenmens]. Die eerste aspek van die Skrif wat volgens Luther aangehoor moet word, is die woorde van die eerste gebod: 'Ek is die Here jou God ...' (Eks 20:2). Vanuit hierdie mededeling moet die Christelike geloof verstaan word, en nie omgekeerd vanuit die religieuse gevoel nie. Teologie begin met ander woorde by dít wat God vir ons te sê het (beginnende by die eerste gebod), en nie by dit wat ons oor God te sê het nie. Teologie eindig vanselfsprekend nie by die aanhoor van God se woord nie, maar word voltrek in die antwoord en belydenis op die spreke van God (vgl. Bayer 1994:106-114; 2003:15).

Die hartklop van Luther se teologie is die prediking. ${ }^{5}$ In die voorrede tot die Kersfeespostille van 1522 (WA 10, 1, 1:11, 13-15) gee hy 'n kort verduideliking oor die bedoeling van die kerklike prediking: Die doel van die prediking 'das du Christum ... auffnehmist unnd erkennist al $\beta$ eyn gabe und geschenck, das dyr von gott geben unf deyn eygen sey' [is dat jy Christus [sal] ... omarm en erken as 'n gawe en geskenk,

4.Alle Afrikaanse vertalings is deur 1 . van wyk gedoen. Waar die oorspronklike uitdrukking nie duidelik en verstaanbaar is nie, word dit in idiomatiese Afrikaan weergegee. Die vertalings het dus nie die bedoeling om Luther se woorde in alle gevalle letterlik weer te gee nie, maar eerder om dit in verstaanbare Afrikaans aan te bied.

5.Meer as 2000 van sy preke het behoue gebly. Luther het nie self sy preke neergeskryf nie. Dit was die werk van diaken Georg Rörer. Wat Luther wel gedoen het, was om 'n seleksie van sy preke in 'traktate' te omskep wat onder die titels 'preke' (Sermon of Predigt) tuisgebring is. 'n Ander waardevolle nalatenskap is sy 'postilles' - preeksketse om predikante en huisvaders te help met die maak van preke. Die eerste bekende korpus dateer uit 1521 getiteld 'Uitleg van die briewe en die evangelies' (WA 7, 458-537). Tot en met 1528 is verskillende reekse postilles geproduseer, wat meestal met die liturgiese kalender en ander kerklike feesdae rekening gehou het (vgl. Zschoch 2010b:317) wat deur God aan jou gegee word en [dat jy Hom] as jou eie [sal] maak]. Volgens Luther is die regte prediking, prediking van die evangelie en 'dauon wirt das hertz unnd gewissen fro, sicher unnd tzufriden, das heyst den Christlichen glawben [ge] predigt. Dauon heyst solch predigt Euangelium' [daarvan word die hart en die gewete vrolik, seker en tevrede, wanneer die Christelike geloof gepreek word. Om hierdie rede word sulke prediking evangelie genoem] (WA 10, 1, 1; 22-12, 1). In Luther se denke is evangelie en prediking wat uit die Bybel voortspruit, wisselterme. Die Bybel is 'eygentlich nitt schrifft, sondern mundlich wort' [eintlik nie skrif nie, maar mondelinge woord] (WA 10, 1, 1; 17, 8) - en die prediking is niks anders nie as om hierdie Woord op te neem en verder te vertel. Luther se preekprogram was bloot die verder vertel van die evangelie - soos wat hy in sy preek op Pinkstermaandag 20 Mei 1532 gesê het: 'Man kan sonst nicht[s] predigen quam de Jesu Christo et fide' ['n Mens kan oor niks anders preek nie as oor Jesus Christus en geloof] (WA 36.180, 10). Sy prediking het verder in die lig van sy onwrikbare geloof in die krag en werking van die verkondigde Woord gestaan. In 'n tafelgesprek sê hy dat God self die loop van die evangelie (cursus evangelii) bepaal - 'Es ist alles divino consilio gesheen' [die voortgang word deur die raad van God bepaal] (WA TR $4,25,18)$. In 'n preek op Sondag Invocabit op 10 Mei 1522 stel hy weer: 'Ich hab nichts gethan, das wort hatt es alles gehandelt vnd außgericht... Ich hab nichts gemacht, ich hab das wort lassen handeln' [Ek het niks gedoen nie, die Woord het alles gedoen en gestalte gegee ... Ek het niks gemaak nie, ek het die Woord laat handel] (WA 10, III, 19, 2, 6).

\section{Wat is teologie?}

Om te beweer dat elke gelowige (WA 10, III, 19, 2, 6) 'n teoloog is, is 'n verrassende uitspraak. Om krities oor die prediking na te dink, is seker vir elke gelowige 'n moontlikheid. Is dít egter slegs wat teologie behels? Indien 'n mens aan Luther die vraag wat teologie nou eintlik is, sou stel, antwoord hy dat dit nie soseer wetenskap (scientia) is nie, maar eerder wysheid (sapientia). Alreeds in 1516 in sy Randopmerkings oor Tauler se Preke het hy van teologie as 'sapientia experimentalis' [ervaringswysheid] (WA 9, 98, 21), gepraat. Vanselfsprekend het Luther nie teologie as wysheid teenoor die wetenskappe geplaas nie. Sy bydrae het met die gedagte te make dat naas en aanvullend tot die wetenskappe, teologie bydra om die mens te begryp. ${ }^{6}$ Vir Luther is teologie 'Ideo Theologicae stinfinita sapientia, quia nunquam potest edisci' ['n oneindige wetenskap, aangesien dit nie volledigafgehandel geleer en bestudeer kan word nie] (WA 40, III, 63, 17-19 in 'n uitleg oor Ps 121:3 in 1532). Om hierdie rede noem hy teologie 'n 'historiese- en ervaringswetenskap'. Deur die gang van die lewe, in biddende omgang met die Bybel, leer 'n mens die genade en geregtigheid van God verstaan as voorwaarde vir'n omvattende begrip van menswees. Hierdie is 'n proses wat nooit afgesluit kan word nie. Voortdurend, op grond van die noukeurige bestudering van die Skrif,

6.Christene Helmer (2013) pleit as Noord-Amerikaner om ruimte vir Luther-navorsing aan staatsuniversiteite. Sy glo dat Luther'n bydrae tot kritiese wetenskapsbeoefening aan staatsuniversiteite. Sy glo dat Luther' $n$ bydrae tot kritiese wetenskapsbeoefening kan lewer - iets waartoe die algemene Godsdienswetenskappe nie in
Minstens om hierdie rede is Luther-navorsing ook vir ons van belang. 
gebed en leiding van die Heilige Gees, kan 'n mens in begrip oor jou bestaan vorder. Luther het by ' $\mathrm{n}$ tafelgesprek in 1532 (WA TR 2, 67, 32-38 = 1353) die saak soos volg saamgevat:

'n Mens moet egter die Heilige Skrif nie volgens menslike insigte beoordeel, verstaan en interpreteer nie, maar in gebed ywerig bedink en oordink. As gevolg van aanvegtinge en die Satan leer 'n mens die Skrif [mettertyd] verstaan deur [voortdurend] daarmee in oefening te bly en om sodoende [lewens- en geloofs] ervarings [met die Skrif] op te doen; en as dít nie gedoen word nie, sal 'n mens niks daarvan verstaan nie, ten spyte van die feit dat 'n mens dit hoor en lees. Die Heilige Gees alleen moet altyd ons Meester en Leermeester wees; en die volgelinge en leerlinge [van Christus] behoort hulle nie te skaam om van hierdie Leermeester te leer nie. ${ }^{7}$

Luther se teenstelling tussen 'wysheid' en 'wetenskap' loop uit op sy gedagte dat teologie 'konflikwetenskap' is (vgl. Bayer 1994:115-127; Köpf 2013:39-53; Lohse 1995:214-223). Teologie praat nie die kennis van ander wetenskappe na nie, aangesien dit iets anders tot die verstaan van die mens en die wêreld aanbied. Wat aangebied word, is God se Woord wat gehoor, geglo en gehoorsaam moet word. Hierdie aanbieding berus op aanhoudende ervaring. Oor en oor word die Woord gehoor, en oor en oor betrek mense dit wat gehoor word, biddend op hulle lewensworsteling. Om hierdie rede kan sy teologie 'sapientia experimentalis' ['eksperimentele wysheid'] genoem word (Bayer 1994:55) - 'n wysheid wat oor tyd ontwikkel deur te luister, te bid, te dink en dit eksistensieel te betrek.

\section{Wat maak van'n teoloog 'n teoloog?}

Pas is gestel dat teologie volgens Luther 'n saak van elke gelowige is. Wat is egter die dinge wat vir 'n Christenmens wesenlik belangrik is om ' $n$ teoloog te word, óf 'Quae faciant theologum?' [wat maak van 'n teoloog 'n teoloog?]. In een van sy tafelgesprekke (WA TR 3, 312, 11-13 = nr 3425) lig hy die volgende ses punte uit: Gratia Spiritus [Genade van die Heilige Gees]; tentatio [aanvegting]; experientia, [geloofservaring]; occasio [geleentheid]; sedula lectio [aanhoudende, gekonsentreerde teksstudie]; en bonarum artium cognitio [kennis en beoefening van die wetenskappe]. Die laaste twee punte is veral die forte van die professionele teoloog, maar gewone lidmate kan ook in 'n mindere mate hierin uitmunt. Dit is egter belangrik dat die eerste drie punte óók vir die professionele teoloog geld. Luther se betoog is dus dat almal in die kerk teologie kan en moet beoefen. Sommige kan egter (op grond van hulle uitgebreide, tegniese taalgebruik) sake meer omvattend en (dalk) meer diepgaande bespreek.

Luther het in sy Voorrede tot die eerste Wittenbergse uitgawe van sy Duitse geskrifte (1539) in 'n korter weergawe gestel wat dit is wat van 'n teoloog 'n teoloog maak. Hy het aan hand van Psalm 119 op die volgende drie sake gewys (WA 50, 657-661):

7.Luther stel: "Man soll aber die heilige Schrift nicht nach unser Vernunft messen, richten, verstehen, und deuten, sondern mit dem Gebet fleißig bedenken und ihr richten, verstehen, und deuten, sondern mit dem Gebet fleißig bedenken und in nachtrachten. So sind die Anfechtungen und der Satan auch ein Ursach, dass man sie ein wenig und etlicher Masse lerne verstehen durch Ubung und Erfahrung; sonst und ohne das verstehet man nimmermehr nichts davon, ob man sie wol höret und lieset. Der heilige Geist muss alda allein Meister und Präceptor sein, der uns lehret, und der Jünger oder Schüler schäme sich nicht, von diesem Präceptor zu lernen.' oratio, meditatio et tentatio [gebed, meditasie en aanvegting] ${ }^{8}$. Ek meen dat daar aan die hand van hierdie begrippe nie net 'n goeie oorsig oor Luther se teologie gekry kan word nie, maar dat daar ook by die meeste belangrike aspekte van sy teologie uitgekom kan word.

\section{Genade van die Gees (gratia Spiritus)}

Mense word nie teoloë op grond van hulle kennis van God, omvattende selfrefleksie, of die begeerte om kennis te genereer nie, maar op grond van die spreke van God deur sy Gees (Ps 33:6). Die genade dat God deur sy Gees, op grond van die verkondiging van die evangelie, tot iemand spreek, is die fondament van alle teologie. Die spreke van God en die luisterende ore van ' $n$ persoon is die eerste stap wat gegee moet word wanneer iemand ' $n$ teoloog wil word. Die eerste stap is nie die kennis en die beoefening van die wetenskap nie. Sowel die gemeente-teoloog as die professionele teoloog begin dus by dieselfde punt. Dit word egter van voltydse teoloë verwag dat hulle die vermoë sal ontwikkel om met groter akkuraatheid oor sekere aspekte van die Bybelse boodskap te kan skryf en praat. Oswald Bayer (2003:18-19) verduidelik hierdie verskil aan die hand van Immanuel Kant se skoolbegrip en wêreldbegrip. Die teologieprofessor maak gebruik van skoolbegrippe wat deur 'n kleiner groepie mense verstaan sal word wat by 'n universiteit doenig is. Die feit dat hierdie taalgebruik nie deur alle lidmate verstaan word nie, beteken nie dat die professor méér van die evangelie af weet as die lidmate nie. Die wêreldbegrip het te make met die taalgebruik wat almal behoort te verstaan. Binne die raamwerk van die wêreldbegrip word daar veral met die gebed (oratio), Skrifmeditasie (meditatio) en aanvegting (tentatio) gewerk. 'n Teoloog (enige ernstige lidmaat) is iemand wat deur aanvegting (konfrontasie met geloofs- en lewensprobleme) al biddend die Skrif benader om daarin te ontdek hoe menswees in die lig van die evangelie verstaan moet word. Volgens Luther is daar geen vasgestelde grens tussen hierdie twee terreine van denke nie. Gewone lidmate kan en moet probeer om soveel moontlik wetenskaplike taalgebruik baas te raak, terwyl professionele teoloë nie met dinge besig behoort te wees wat gewone lidmate nie aangaan nie.

\section{Aanvegting (tentatio)}

Aanvegting (of ook versoeking) het ten diepste met die vrees te make dat die dood op die 'bose' sal uitloop. Die diepste punt van boosheid kom op die algehele vernietiging van die gemeenskap met God neer. Aanvegting is dus iets radikaler as intellektuele twyfel of vrees dat die fondamente van jou wêreldvertroue geskud sal word. Aanvegting het met die vrees te make tot God jou vyand sal word en dat Hy jou die ergste iets denkbaars sal aandoen, naamlik om Hom van jou te onttrek. Luther sê in die voorrede tot sy Duitse geskrifte (WA 50, 660, 35-661, 14) dat hy nie tot 'n deeglike teoloog

8.Luther draai die middeleeuse volgorde van "lectio-meditatio-oratio-contemplatio" doelbewus om, om daardeur die belangrikheid van gebed te beklemtoon ( $\mathrm{vgl}$ Goldmann 2014:121). 
sou kon ontwikkel het, indien dit nie vir sy aanvegting in die klooster gewees het nie. Sy ernstige worsteling om God se geregtigheid het hom daartoe gelei om die Bybel en die inhoud van die Bybel te ontdek. Sy stryd met die duiwel het hom God se beloftes in die Bybel laat ontdek - en dít het aan hom heilsekerheid gebied. Heilsekerheid het nie met (wetenskaplike) kennis te make nie, maar met die ervaring met die Woord. Teologie kan met baie (relevante) aardse probleme besig wees, maar as dit nie met die groot probleme soos die dood en God se geregtigheid vanuit die Skrif worstel nie, sal dit gou oninteressant raak. Luther se teologie beskerm ons juis teen oninteressantheid.

\section{Ervaring (experientia) en gebed (oratio)}

Met ervaring bedoel Luther nie 'n ervaring wat ek maak of opdoen nie (actio), maar 'n ervaring wat ek ly (passio) - dit is die ervaring wat ek van God se Woord opdoen in my ervaring van die aanvegting. Luther (WA TR 1, 16, $13=$ $\mathrm{nr} 46$ ) het sy gedagtegang soos volg in 'n tafelgesprek van 1531 uitgedruk: 'Sola ... experientia facit theologum' [Alleen die ervaring maak die teoloog]. Hiermee bedoel hy nie dat dit gewone, menslike lewenservarings is nie, maar wel die ervarings van en met die Woord wat van iemand ' $n$ teoloog maak. Luther se uitdrukking sola experientia moet daarom nie teenoor sy oortuiging van sola scriptura gestel word nie, aangesien die ervaring wat vir hom saak maak die ervaring met die Woord is. Sy gedagtes oor ervaring is aanvanklik deur die monastiese ervaringsteologie van Bernard van Clairvaux gevorm, wat op hom as monnik 'n groot indruk gemaak het (Beutel 2010c:454; Köpf 2013:56). Mettertyd, na mate hy sy eie verstaan van die Skrif ontwikkel het, het hy sy eie uitleg aan ervaring begin gee. Volgens Luther is ' $n$ teoloog nie iemand wat besondere lewenservarings opgedoen het nie, maar iemand wat die diepte en krag van die Woord ervaar het en ander dit ook laat ervaar. Luther betoog nie dat teologie verskraal moet word tot die blote lees van en denke oor die Bybel nie. Die lees van die Bybel moet met die ganse ervaring van menswees geïntegreer word. Hy sê in 1528 in 'n voorlesing oor 1 Timoteus 3:4: 'Sacra scriptura non vult sola cogitatione comprehendi, sed per experientam prorsus inculcari' [Die Heilige Skrif wil nie net deur die denke begryp word nie, maar deur die ervaring geheel en al ingeprent word] (WA 26, 55, 35-36). Aan tafel het hy (WA TR 2, 84, 19-20) ook gesê: 'Die schrifft versteht khein mensch, und ist unmuglich, es kom in den hinein, id est, experiatur' [Geen mens kan die Skrif verstaan nie; dit is onmoontlik indien dit nie vanuit die ervaring gedoen word nie]. Skrif en ervaring word net op een wyse bymekaargebring, en dit is deur die prediking.

Die prediking is egter nie 'n towerstaf nie. Elke Christen bly op grond van verskillende lewenservarings, in 'n stryd tussen geloof en ongeloof vasgevang. Daarom is prediking en Christelike eksistensie op gebed en smeking aangewese. Volgens oorlewering was Luther se laaste woorde voor sy sterwe: 'Wir sein pettler. Hoc est verum' [Ons is bedelaars. Dit is seker] (WA TR5, 318, 2-3). Hierby kan die woorde van 'n preek oor Johannes 15 uit 1537 gevoeg word: Betler sind wir auff erden (wie Christus auch selbs gewest ist), aber fur Gott sind wir uberschüttet mit allen gütern, das die welt gegen uns elend und blos ist [Ons is bedelaars op aarde (soos Christus self ook gewees het), maar vir God is ons oordek met alle goedheid [ter beskutting teen] die ellende en boosheid van die wêreld] (WA 45, 537, 26-28). Luther se gedagte dat ons uiteindelik maar net bedelaars is, het ook te make met die jarelange worsteling om die Woord reg te verstaan. Die konteks van sy laaste woorde dui op die gedagte dat die korrekte uitleg van tekste op jarelange lewenservaring en worsteling met die saak van die teks te make het. Om byvoorbeeld Virgilius se tekste oor boerdery te verstaan, moet jy self vir'n langer tyd boer en op die uitleggeskiedenis van sy tekste staatmaak. Dieselfde geld vir die Bybel. 'n Mens moet oor 'n lang tyd daarmee worstel en op die interpretasiegeskiedenis staatmaak. In die lig hiervan is die mens ' $n$ bedelaar. Insig en begrip val nie ewe skielik uit die hemel nie. Vir 'n lang tyd moet 'n mens smekend na die regte uitleg soek (vgl. Schilling 2010:105-106 vir 'n uitleg van hierdie woorde). In die Voorrede tot sy Duitse geskrifte skryf hy (WA 50, 659, 5-21) hierdie belangrike woorde oor Skrifuitleg en gebed:

Eerstens moet jy weet dat die Heilige Skrif só 'n boek is wat alle ander boeke tot narrigheid maak, aangesien hulle nie soos hierdie boek, iets oor die ewige lewe leer nie. Daarom moet jy jou [menslike] verstandsvermoë en begrip eerder versaak, aangesien jy daarmee nie [die Bybel] kan verstaan nie. Om [met hierdie pogings] te volhard, sal jy jouself en ander mense (soos wat met Lucifer gebeur het) uit die hemel tot in die hel laat val. Maar kniel eerder in jou binnekamer neer en bid met opregte nederigheid en erns tot God, dat Hy jou om sy Seun se ontwil, die Heilige Gees sal skenk, wat jou [verstand] sal verlig, leiz en tot insig sal bring. ... Soos wat jy kan sien, het Dawid ... altyd gebid: 'Leer my Heer, onderrig my, lei my ...' ten spyte daarvan dat hy die tekste van Moses [die eerste vyf boeke van die Bybel] en ander Bybelboeke goed geken het, dit daagliks gehoor en gelees het; hy wou [ten spyte van sy kennis], nogtans die regte leermeester van die Skrif by hom gehad het. Hy wou nie met behulp van sy menslike verstand die Bybel bemeester nie. Uit só 'n poging word slegs 'n klomp onsin gebore, wat daarop neerkom dat gedink word dat die Skrif aan jou onderdanig is en dat jy dit met jou menslike verstand kan bemeester, soos wat 'n mens met die fabels van Esopus kan doen, sonder die Heilige Gees en gebed. ${ }^{9}$

\section{Geleentheid (Occasio)}

Teologie word gemaak wanneer mense wat biddend die Bybel bestudeer die geleenthede wat hulle toeval, gebruik. Luther (WA 20,1-203) sluit aan by Prediker (wat hy in 1526 gekommenteer het) wat dit stel dat geleenthede ons toeval en dat hierdie geleenthede, hierdie uur, hierdie oomblik

9.Luther stel: "Erstlich sollst Du wissen, dass die heilige Schrifft ein solch Buch ist, das aller ander Bucher Weisheit zur Narrheit macht, weil keins vom ewigen Leben lehret on dies allein. Darum sollst Du an deinem Sinn und Verstand stracks verzagen. Denn damit wirst Du es nicht erlangen, Sondern mit solcher Vermessenheit dich selbst und andere mit dir stürzen vom Himmel (wie Lucifer geschah) in Abgrund der Höllen. Sondern knie nieder in deinem Kämmerlein und bitte mit rechter Demut und Ernst zu Gott daß er dir durch seinen lieben Sohn wolle einen heiligen Geist geben, der dich Gott, daß er dir durch seinen lieben Sohn wolle einen heiligen Geist geben, der dich erleuchte, leite und Verstand gebe.... Wie du siehest, daß David immer bittet: Lehre mich, HERR, Unterweise mich, führe mich ... So er doch den Text Mosi und ander meh Bücher wohl kundte, auch täglich höret und lase, Noch will er den rechten Meister de Schrifft selbst dazu haben, Auf daß er ja nicht mit der Vernunft drein falle und sein selbst Meister werde. Denn da werden Rottengeister aus, die sich lassen duncken, die Schrift sei ihnen unterworfen und leichtlich mit ihrer Vernunft zu erlangen, als wäre es Esopus Fabeln, da sie keins heiligen Geists noch Betens zu durffen.' 
aangegryp moet word en dat daar dadelik gehandel moet word. Binne hierdie verband blyk iets van Luther se verstaan van vryheid. Christene is vry om dadelik te handel. Hulle is vry van die muilband van die noodlot en van tragiek. Christene wag nie op ander om iets te doen nie, en beskuldig ander ook nie dat niks gebeur nie. 'Greif zu, weils Zeit ist. Nunc, nunc, die weil das Nunc da ist' [Slaan toe, terwyl dit tyd is. Nou, nou, solank die nou daar is!], vermaan Luther in 'n tafelgesprek (WA TR 6, 359, 36-37).

Luther het na sodanige geleentheid binne verskillende verbande verwys. In 1524 skryf hy (WA 15, 32, 4-13) 'n traktaat aan die stadshouers in Duitsland en vermaan hulle om dadelik te begin om Christelike skole op te rig. Binne 'n ander konteks vermaan hy sy kollegas om die Skrif dadelik weer opnuut uit lê en te interpreteer aangesien dit nie deur die kerkvaders vir eens en vir altyd gedoen is nie. Van hulle word nie verwag om 'n nuwe evangelie te skep nie, maar om die ou waarhede nuut te sê. Hierdie nuwe, geaktualiseerde uitleg moet op die duidelike onderskeid tussen wet en evangelie konsentreer. Vir Luther (vgl. Bayer 2003:22-23) is die occasio die noodsaak om hierdie twee sake te onderskei. Die vroeë jare van die Reformasie was vir Luther nie die tyd van die wet (tempus legis) nie, maar die tyd van die evangelie (tempus euangelii). Volgens hom moes daar onverwyld op die onderskeid tussen wet en evangelie gewys word. Dít het hy nie chronologies bedoel nie, maar wel kairologies.

Die onderskeid tussen wet en evangelie is een van die belangrike hoekpilare van Luther se teologie. Oor hierdie onderskeid sê hy in 1521 oor Die uitleg van die briewe en die evangelies (WA 7, 502, 34-35): 'Pene universa scriptura totiusque Theologiae cognitio pendet in recta cognitione legis et Euangelii' [Inderdaad, die hele Bybel en alle teologiese insig het hulle ankerpunt in die regte verstaan van wet en evangelie]. Op 06 September 1538 sê hy in sy Disputasie teen diegene wat die wet verwerp (WA39, 1, 552, 12-13) die volgende oor die onderskeid tussen die wet en die evangelie: 'Haec qui bene novit distinguere, bonus est theologus' [Wie weet om dít goed te onderskei, is 'n goeie teoloog], en 'Qui istas 2 distinctiones bene novit, gratias agat deo et sciat se Theologum' [Wie die noodsaaklikheid van die onderskeiding van hierdie 2 verstaan, mag God dank met die wete dat hy 'n teoloog is]. Luther het die antiteses en teensprake nie uit sy duim gesuig nie, maar het hierdie benadering in die Bybel self gevind. Volgens hom moet hierdie antitetiese of dialektiese taalgebruik erken word, en as ' $n$ metode gebruik word om die Bybel te interpreteer. Hy (WA 40, 1, 391, 3-5) skryf in 1535 in sy Kommentaar op Galasierrs: 'Scriptura habet modum, quod plena antithesibus; et est quoddam genus fecundum, interpretari scripturam per Antitheses ete as videre' [Die Bybel het die uniekheid dat dit vol antiteses is; en dít is heel vrugbaar om die antiteses raak te sien en om die Bybel vanuit hierdie (perspektief) te interpreteer]. Volgens Luther handel hierdie 'onderskeidingsleer' nie net oor die opheldering van vermeende teenstellings nie. Die Bybel, as 'n realistiese boek, bring die teenstellings, teensprake en onoorbrugbare konflikte van die lewe na voreen dít moet gerespekteer word. 'n Poging om alles reglynig, sonder teensprake en teenstellings geïnterpreteer te kry, doen onreg aan die Bybel en die werklikheid. Dit kom neer op 'n wanhopige poging om sekerheid (certitudo) uit reglynige morele of metafisiese oordele te tap (Beutel 2010b:450-453).

Die tyd van die sestiende eeu het vereis dat die evangelie nie tot wet vervlak word nie. Die verskil moes uitgewys word sodat die evangelie weer duidelik gehoor kon word. Om hierdie onderskeid konkreet uit te spel, is nie'n metodologiese aangeleentheid nie, maar 'n geluk wat hulle (in daardie tyd) toegeval het. Die Heilige Gees het aan hulle hierdie kuns, as guns van God laat toeval. Die geleentheid het van God gekom (WA TR 2, 4, 7-16=nr 1234 van 1531). Die vraag wat dus gevra moet word, is: Wat laat God ons vandag toeval? Wat wil die Gees hê moet ons vandag uitspel?

\section{Meditasie (Meditasio) en sorgvuldige teksstudie (sedula lectio)}

Op die Ryksdag van Worms (1521) het die keiser spottend gevra of die Bybel (en die Bybel alleen) die regula Lutheri (WA $15,266,7-21)$ is? Luther antwoord deur sy woorde van 1521 te herhaal: 'Mein ding ist eyttel schrifft' [My ding is net die Skrif] (WA 8, 341, 21). Luther se konsentrasie op die Woord alleen (sola scriptura) het op 'n totale breuk met die teologiese tradisie waaruit hy gekom het, neergekom. Hierdie breuk met sy teologiese tradisie, was 'n langsame proses en het nie plotseling plaasgevind soos dit vir baie lank voorgestel is nie (vgl. Leppin 2010:107-164). Die breuk was hoofsaaklik op die belangrike rol van Petrus Lombardus ${ }^{10}$ in die teologiese onderrig toegespits.

Aangesien teologie oor die Bybel handel, verwag hy dat die gelowige die Woord sal lees en daaroor sal mediteer (meditatio). In die voorrede tot sy Duitse geskrifte van 1539 (WA 50, 660, 20-29) skryf hy dat 'n mens daaroor moet nadink, peins, bid en wonder. Daar moet stilte wees en jy moet aandag gee wanneer jy dit doen. Die Bybel moet weer en weer gelees word, en die Heilige Gees moet gebid word om duidelikheid aangaande wat daar staan. Daar moet egter ook 'n sorgvuldige studie van die Bybel gemaak word. Die Bybel moet in diepte, oor 'n lang tydperk, met alle menslike middels tot ons beskikking, bestudeer word. Om Luther se verstaan van die Skrif en sy bevordering van 'wetenskaplike eksegese' ${ }^{11}$ beter te begryp, is nog 'n paar opmerkings nodig (vgl. Beutel 2010a vir 'n oorsig oor sy verstaan van die Skrif).

10.Luther het hom vir lank met die Sentenzen of die uitsprake versameling van die kerkvaders deur Petrus Lombardus besig gehou. Vir sy Baccalaureus (Oktober 1509) het hy al randopmerkings oor hierdie geskrif gemaak. In 1517 pleit hy dat teologiese onderrig nie met Lombardus moet begin nie, maar met die Skrif self. Vanaf 1520 eis hy met dringendheid dat die klem vanaf die uitleg van die kerkvaders na die bestudering van die bybelse teks moet verskuif. Om hieraan uitvoering te gee, moes hy, met behulp van Melanchthon die hele kurrikulum verander (vgl. Köpf 2013:34-50).

11.Die fout word dikwels gemaak deur te meen dat Luther se aanstelling as OuTestamentikus, primêr vir die eksegese verantwoordelik, was. Hy is nie as lectura in biblia aangestel nie, maar as lectura in theologia. In die Middeleeue was biblia, sacra scriptura, sacra doctrina en theologias in onieme, terwyl die onderskeid tussen die teologiese vakke 'n produk van die laat sestiende eeu is. Luther self het teologie (theologia) en die Heilige Skrif (biblia) as sinonieme gebruik (vgl. sy geskrif teologie (theologia) en die Heilige Skrif (biblia) as sinonieme gebruik (vgl. sy geskrif
van 1521 Warum des Papstes und seiner Jünger Bücher von D.M. Luther verbrannt sind - WA 7, 161, 8.18) 
Vir Luther was Bybeluitleg nie 'n buitengewoon moeilike aangeleentheid nie, aangesien die Bybel homself uitlê ('Scriptura ... sui ipsius interpres' - WA 7, 97, 21-23 skryf hy in 1521 in reaksie op Leo $X$ se uitreiking van die bul); die uitlê moet sodanig wees dat alles na Christus heenwys. Christus is vir hom die saak van die Skrif in persoon ('Tolle Christum e scripturis, quid amplius in illis invenies'; WA 18, $606,29)$. Ten spyte van al die veelvoud in die Bybel is dit tog 'ungetzweyfflet, das die gantze schrifft auff Christum allein ist gericht' [bo alle twyfel dat die ganse Skrif op Christus alleen gerig is] (WA 10, 2, 73, 16). In alle eksegetiese en hermeneutiese arbeid is die belangrike vraag uiteindelik ' $o b$ sie Christum treyben' [of dit Christus betuig] (WA DB 7, 384, 27). Mense uit die Gereformeerde skolastiek mag dit vreemd vind dat Luther nie aan die Bybel gedink het in terme van 'n geslote boek met duidelik afgebakende indelings nie. Hy kon byvoorbeeld na die Psalms verwys as 'ein kleine Biblia' (WA $D B$ 10, 1, 99, 24 101, 2); hy het selfs na enkele teksverse soos Genesis 24:7 en Lukas 2:11 verwys as samevattings van die hele Skrif 'totam scripturam in ein beutel' (WA 37, 237, 34 en 43, 316, 26-28); dan het hy ook na die kategismus verwys as der leyen biblia [die leke-Bybel] (WA 30, 1, 27, 26). Hy het van die Apostolicum gesê 'Das Credo ... ist meine Bibel' [Die Credo ... is my Bybel] (WA 37, 55, 13).

Die Bybel was nie net vir hom 'n boek wat gelees moes word nie. Dit moet ook toegepas en gebruik word in en vir die lewe. Hy skryf in 1529 in sy voorrede tot Melanchthon se uitleg van Kolossense (WA 31, 167, 24-27), die Bybel is 'doch ja nicht Lesewort, wie sie meinen, Sondern eitel Lebewort ... die nicht zum speculieren und hoch zu tichten sondern zum leben und thun dargesetzt sind' [tog nie leeswoord, soos julle dink nie, maar is eintlik lewenswoord ... wat nie geskryf is vir spekulasie en digkuns nie, maar vir (die) lewe]. Vir die Bybel om die boek van die lewe te word, is voortdurende bestudering daarvan nodig. Voortdurende omgang met die Bybel as die 'leerskool van die geloof' is nodig sodat ons as Christene 'unserm Herrn Jhesu Christo ... nachreden, wie er uns vorredet' [ons Heer Jesus Christus ... kan naspreek soos Hy ons voorsê] (WA 45, 205, 31-33), en 'nicht nur von Gott, sondern auch wie Gott zu reden wissen' [nie alleenlik van God kan praat nie, maar ook weet om soos God te kan praat] (WA 41, 11, 9-11).

\section{Die onderwerp (Gegenstand) van die teologie}

Luther se teologie kan saamgevat word as die daarstelling van die barmhartigheid van God as die grond vir geloof (AxtPiscaler 2013:78). Hierdie evangelie van die onverdiende genade van God, saamgevat in die regverdiging van die sondaar deur God in Christus, het Luther uit sy studie van Paulus leer ken. Dit is hierdie nuutgevonde 'geregtigheid van God' wat vir hom die paradys laat oopgaan het, soos hy dit in die Voorrede tot die eerste band van die Latynse geskrifte stel. Die volgende aanhaling (WA 54, 185, 21-186, 16) bevat iets van Luther se worsteling as monnik en sy ontdekking van die geregtigheid van God by Paulus. In 'n sekere sin is dit 'n samevatting van die kern van Luther se teologie:

Ek egter, ek wat so skandalig as monnik geleef het, wat my as sondaar met ' $n$ algehele onrustige gewete voor God bevind het en nie daarop kon vertrou, dat deur my genoegdoening [met God] versoen te wees nie; [ek] het God nie liefgehad nie, ja ek het eerder die regverdige en sonde-strawwende God gehaat en het my in stilte teenoor God opgeruk, as dit nie lasterlik was nie, dan met 'n onophoudelike gemurmel en het gesê: Asof dit nie genoeg is dat die ellende en allerlei onheil as gevolg van die erfsonde, op die ewig verlore sondaars neerdruk nie, is dit nie net die wet van die tien gebooie nie, maar ook nog God wat deur die evangelie smart op smart daaraan toevoeg en ons met sy geregtigheid en sy toorn toetakel! So was ek verwoed met my wilde en verwarde gewete. Nogtans het ek angstig by Paulus aangeklop [Rom 1:17], uitgedroog van dors om uit te vind wat Paulus te sê het. Totdat ek, deur God se erbarming, dae en nagte nadenkend my aandag toegespits het op die verbinding van die woorde, naamlik: 'Die geregtigheid van God word daarin geopenbaar' en dan verder soos daar geskryf staan: 'Die regverdige leef uit geloof'. Toe het ek begin om die geregtigheid van God te verstaan as sy gawe waardeur die gelowige bestaan; en wel as geloof, [het ek besef] dat die sin van alles op die volgende neerkom: Deur die evangelie word die geregtigheid van God geopenbaar en wel as passiewe [geregtigheid], waardeur die barmhartige God ons regverdig maak, deur die geloof, soos daar geskryf is: 'Die regverdige (of regverdig verklaarde) leef uit die geloof'. Van hier af het ek soos 'n nuut-geborene gevoel en deur geopende deure die paradys binne gestap. Op eens is daar aan my 'n ander gesig van die Skrif as geheel getoon [...] En soveel as wat ek die woord geregtigheid van God vantevore ten diepste gehaat het, met soveel liefde kon ek dit nou op die voorgrond stel as die allermooiste woord. So het hierdie teks by Paulus vir my werklik die hek tot die paradys geword. ${ }^{12}$

Hierdie gedagtes het hy alreeds in sy uitleg van Psalm 51 saamgevat as dít waarop teologiese kennis neerkom. Twee aanhalings gee 'n goeie idee wat Luther (WA 40, 2; 327, 2-4 en 40, 2, 328, 17-20) wou sê:

Die kennis oor God en mens is die Goddelike en eintlike teologiese kennis, en wel kennis oor God en mens, met die uiteindelike bedoeling dat hulle op die regverdigende God en die mens as sondaar betrek word, sodat die eintlike onderwerp van die teologie die aangeklaagde en verlore mens en die regverdigende en reddende God is. ${ }^{13}$... Die kenmerkende onderwerp van die

12.Luther stel dat: 'Ego autem qui me utcunque irreprehensibilis monachus vivebam, sentirem coram Deo esse peccatorem inquietissimae conscientiae, nec mea satisfactione placatum confidere possem, non amabam, imo odiebam iustum et punientem peccatores Deum, tacitaque si non blasphemia, certe ingent murmuratione indignabar Deo, dicens: quasi vero non satis sit, miseros peccatores murmuratione indignabar Deo, dicens: quasi vero non satis sit, miseros peccatores
et aeternaliter perditos peccato originali, omni genere calamitatis oppressos esse per legem Decalogi, nisi Deus per euangelium dolorem dolori adderet, et etiam per euangelium nobis iustitiam et iram suam intentaret, Furebam ita saeva et perturbata conscientia, pulsabam tamen importunus eo loco Paulum [Rom 1:17], ardentissime sitiens sciri, quid S Paulus vellet. Donec miserente Deo meditabundus dies et noctes connexionem verborum attenderem, nempe: Iustitia Dei revelatur in illo, sicut scriptum est: lustus ex fide vivit. Ibi iustitiam Dei coepi intelligere eam qua iustus dono Dei vivit, nempe ex fide, et esse hanc sententiam, revelari per euangelium iustitiam Dei, scilicet passivam, qua nos Deus misericors iustificat per fidem, sicut scriptum est: Iustus ex fide vivit. Hic me prorsus renatum esse sensi, et apertis portis in ipsam Paradisum intrasse; ibi continuo alia mihi facies totius et apertis portis in ipsam Paradisum intrasse; ibi continuo alia mihi facies totius scripturae apparuit ... lam quanto odio vocabulum "iustitia Dei" oderam ante, tanto amore dulcissimum mihi vocabulum extollebam, ita mihi iste locus Pauli fuit
vere porta paradisi.'

13.Volgens Luther: 'Cognitio dei et hominis est sapientia divina et proprie theologica, Et ita cognitio dei et hominis, ut referatur tandem ad deum iustificantem et hominem peccatorem, ut proprie sit subiectum Theologiae homo reus et perditus et deus iustificans vel salvator.' 
teologie is die mens, wat aan die sonde skuldig en daaraan onderworpe is, en God, wat die sondige mens regverdig en red. Wat buite hierdie onderwerp om in die teologie nagevors en bevorder word, is dwaling en gif. $^{14}$

In die lig van wat hier bo gestel is, blyk duidelik dat die hart van die reformatoriese teologie die regverdigingsleer is. Luther het in 1537 in die Promosiedisputasie van Palladius en Tilemann (WA 39/1, 205, 2-5) gesê:

Die artikel van die regverdiging is die meester, vors, heer, rigtinggewer en regter oor allerlei leeraangeleenthede. Dit bewaar en stuur die kerklike leer in die regte rigting en skerp ons gewete op voor God. Sonder hierdie artikel is die wêreld niks anders as dood en duisternis nie..$^{15}$

Dit is werklik jammer dat die regverdigingsleer nooit in die Afrikaanssprekende kerke aandag gekry het nie, en dat die gedagte van sin hierdie tema verdring het. My vorige pleidooie (Van Wyk 2001 en 2011) het op dooie ore geval. Op hierdie stadium wil ek beweer dat daar met die tema $\sin$ nie net afskeid geneem word van die reformatoriese teologie nie, maar van die Christelike geloof as sodanig.

\section{Nederigheid}

Hierdie artikel word afgesluit met Luther se perspektief op nederigheid - nederigheid in spiritualiteit en teologiebeoefening. Van homself sê Luther in sy geskrif oor die Onvrye vermoë van die wil (WA 18, 786, 25-26): 'Ego vero nihil habeo et sum, nisi quod Christianum esse me prope glorier' [Ek, egter, het niks en is niks, behalwe dat ek amper daarop kan roem om 'n Christen te wees]. Om sy nederigheid te illustreer, word met 'n veelseggende aanhaling afgesluit (WA 50, 661, 31-48) wat uit die laaste gedeelte van die Voorrede tot die eerste Wittenbergse uitgawe van die Duitse geskrifte (1539) kom. Hierdie aanhaling moet gelees word teen die agtergrond van sy onwilligheid om sy geskrifte aan die breë publiek bekend te stel. Hy het nie gemeen dat sy teologiese bydrae iets buitengewoon was nie, en in elk geval het hy gemeen dat mense eerder die Bybel moet lees:

Voel jy dat jy 'n prominente mens is en is jy van mening dat jy alles in 'n greep het, en spog jy met jou eie boeke, leer of geskrifte, so asof jy dit heel voortreflik gemaak en treffend gepreek het, en hou jy ook daarvan dat jy voor ander mense geprys word, en wil jy ook nog geloof word selfs wanneer jy treurend rondsit of ook nalaat [om ywerig te werk] - is jy só iemand my liefste mens, gryp jouself dan aan die ore, en wanneer jy dit behoorlik vasvat, dan sal jy 'n paar groot, lang, growwe donkie-ore voel ... Die slotsom: laat ons eer soek en hoogmoedig wees op plekke waar dit vanpas is. In hierdie boek, kry God alleen die eer. En dit beteken: God weerstaan

14. Nam Theologiae proprium subiectum est homo peccati reus ae perditus et Deus iustificans ae salvator hominis peccatoris. Quicquid extra hoc subiectum in Theologia quaritur aut disputatur, est error et venum.'

15.Luther poneer: 'Articulus iustificationis est magister et princeps, dominus, rector et iudex super omnia genera doctrinarum, qui conservat et gubernat omnem doctrinam ecclesiasticam et erigit conscientam nostram coram Deo. Sine hoc articulo mundus est plane mors et tenebrae.' die hoogmoediges, maar aan die nederiges gee Hy genade. Aan Hom kom die eer toe in alle ewigheid. Amen. ${ }^{16}$

\section{Erkenning Mededingende belange}

Die outeur verklaar hiermee dat hy geen finansiële of persoonlike verbintenis het met enige party wat hom nadelig of voordelig kon beïnvloed het in die skryf van hierdie artikel nie.

\section{Literatuurverwysings}

Axt-Piscaler, C., 2013, Was ist Theologie? Klassische Entwürfe von Paulus bis zur Gegenwart, Mohr Siebeck, Tübingen.

Bayer, O., 1994, Theologie, Mohn, Gütersloh. (Handbuch SystematischerTheologie, Band 1).

Bayer, O., 1995, 'Wer ist Theologe?', in M. Beintker, E. Maurer, H. Stoevesandt \& $\mathrm{H}$. Ulrich (Hrsg.), Rechtfertigung und Erfahrung: Für Gerhard Sauter zum 60. Geburtstag, pp. 208-213, Gütersloher Verlagshaus, Gütersloh.

Bayer, O., 2001, 'Die ganze Theologie Luthers', Kerygma und Dogma 47(4), 254-274.

Bayer, O., 2003, Martin Luthers Theologie: Eine Vergegenwärtigung, Mohr Siebeck, Tübingen.

Beutel, A., 2010a, 'Strukturen: Theologie als Schriftauslegung', in A. Beutel (Hg.), Luther Handbuch, pp. 444-449, Mohr Siebeck, Tübingen.

Beutel, A., 2010b, 'Strukturen: Theologie als Unterscheidungslehre', in A. Beutel (Hg.) Luther Handbuch, pp. 450-454, Mohr Siebeck, Tübingen.

Beutel, A., 2010c, 'Strukturen: Theologie als Erfahrungswissenschaft', in A. Beutel (Hg.), Luther Handbuch, pp. 454-459, Mohr Siebeck, Tübingen.

Beyer, M., 2010, 'Luther ausgaben', in A. Beutel (Hg.), Luther Handbuch, pp. 2-8, Mohr Siebeck, Tübingen.

Cobbers, A., 2013, Auf den Spuren von Martin Luther: Die Lebensstationen des grossen Reformators, Jaron Verlag, Berlin.

Goldmann, M., 2014, 'Oratio - Meditatio - Tentatio: Impulse Martin Luthers für eine evangelische Spiritualität', Luther 85, 115-124.

Helmer, C., 2013, 'Luther, Theology and the University', Luther Jahrbuch 80, 60-76.

Kettunen, O., 2012, 'Der Schlüssel zu Luthers reformatorischer Theologie', Luther Jahrbuch 83, 80-90.

Köpf, U., 2013, 'Martin Luthers Beitrag zur Universitätsreform', Luther Jahrbuch 80, 31-59.

Korsch, D., 2010a, 'Aneignungen: Die religiöse Leitidee', in A. Beutel (Hg.), Luther Handbuch, pp. 91-97, Mohr Siebeck, Tübingen.

Korsch, D., 2010b, 'Theologische Prinzipienfrage', in A. Beutel (Hg.), Luther Handbuch, pp. 353-362, Mohr Siebeck, Tübingen.

Leppin, V., 2010, Martin Luther, 2. durchgesehene, aktualisierte Auflage, Wissenschaftliche Buchgesellschaft, Darmstadt. (Gestalten des Mittelalters und der Rennaissance, Herausgegeben von Peter Herde).

Lohse, B., 1995, Luthers Theologie in ihrer historischen Entwicklung und in ihrem systematischen Zusammenhang, Vandenhoeck, Göttingen.

Luther, M., [1516] 1893, 'Randbemerkungen zu Taulers Predigten', WA 9, 95-104.

Luther, M., [1517] 2006, 'Disputatio contra scholasticum theologiam', WA 1, 224-228, nuut opgeneem in W. Härle (Hrsg.), 2006, Martin Luther: Lateinisch-Deutsche Studienausgabe, Band 1, Der Mensch vor Gott, unter Mitarbeit von Miachael Beyer, pp. 19-33, Evangelische Verlagsanstalt, Leipzig.

Luther, M., [1517/1518] 1899, 'Vorlesung über den Hebräerbrief', WA 57, 3, 1-325.

Luther, M., [1520] 1897, 'Assertio omnium articlorum M. Lutheri per ballum Leonia $\mathrm{X}^{\prime}$, WA 7, 94-101.

Luther, M., [1521] 1889, 'Evangelium verdeutscht und ausgelegt', WA 8, 340-343.

Luther, M., [1521] 1897, 'Ennarrationes epistolarum et evangeliorum, quas postillas vocant', WA 7, 458-537.

Luther, M., [1521] 1897, 'Warum des Papstes und seiner jünger Bücher von D.M. Luther verbrannt sind', WA 7, 161-164.

Luther, M., [1522] 1905, 'Predigt am Sonntag Invocabit 10. Mai 1522', WA 10, III, $19-22$.

Luther, M., [1522] 1910, 'Weihnachtspostille (Ein klein Unterricht)', WA 10, 1, 1, 8-18.

16.Volgens Luther: 'Fülest du dich aber / vnd lessest dich düncken / du habest es gewisz / vnd kützelst dich mit deinen aigen Büchlein / leren oder schreiben / als habest du vnd küzelst dich mit deinen aigen Büchlein /leren oder schreiben / als habest du es seer köstlich gemacht / vnd treflich gepredigt / Gefellet dir auch seer / daz man dich für andern lobe Wilt auch villeicht gelobt sein / Sonst würdestu trawren oder ablassen. Bist du der har / Lieber / so greiff dir selber an deine Ohren /Vnd greiffest du recht / so wirst du finden ein schön par / grosser / langer / rauher Eselszohren Summa / Last vns ehre suchen / vnd hochmütig sein / wo wir mögen / In diesem Buch ist Gottis die Ehre allein / Vnd heisst. Deus superbis resistit, humilubus autem dat gratiam (1 Petr 5,5). Cui est gloria in secula seculorum. Amen.' 
Luther, M., [1522-1546] 1835-1987, WA DB = Deutsche Bibel, Bände 1-5.

Luther, M., [1523] 1900, 'Das eyn christliche versamlung odder gemeine recht und macht habe, alle lere zu urteilen und lerer zu berufenenn und abzusetzen: Grund und ursach aus der schrift', WA 11, 408-416.

Luther, M., [1524] 1899, 'An die Ratsherren aller Städte deutschen Landes, das sie christliche Schule aufrichten und halten sollen', WA 15, 27-53.

Luther, M., [1524] 1899, 'Zwei kaiserliche uneinige und widerwärtige gepott den Luther betreffend, 1524', WA 15, 254-277.

Luther, M., [1525] 1908, 'De servo arbitrio', WA 18,600-787, nuut opgeneem in W. Härle (Hrsg.), 2006, Martin Luther: Lateinisch-Deutsche Studienausgabe, Band 1, Der Mensch vor Gott, unter Mitarbeit von Miachael Beyer, pp. 219-661, Evangelische Verlagsanstalt, Leipzig.

Luther, M., [1526] 1898, 'Vorlesung über den Prediger Salomo, 1526: Annotationes in Ecclesiasten 1532', WA 20, 1-203.

Luther, M., [1528] 1909, 'Vorlesung über 1 Timotheus: Schriften 1528', WA 26.

Luther, M., [1528] 1910, 'Zweite Predigtreihe (Katechismen) am 14. September Anni 1528', WA 30,1,27-57.

Luther, M., [1529/1532] 1913, 'Vorrede zur Melanchthons Kommentar zu Kolosser 1529', WA 31,1,67,1-30.

Luther, M., [1531/1535] 1911, 'In epistolam S. Pauli ad Galatas Commentarius ex praelectione D. Martini Lutheri (1531) collectus 1535', WA 40, 1, 1-691.

Luther, M., [1531-1546] 1912-1921, WA TR= Tischreden, Bände 1-6.

Luther, M., [1532] 1909, 'Predigt am Pfingstmontag am 20. Mai', WA 36, 180-184.

Luther, M., [1532] 1910,'Predigt über Psalm 5', WA 41, 8-17.

Luther, M., [1532] 1930, 'In XV Psalmos graduum (Ps 121:3)', WA 40, III, 38-67.

Luther, M., [1533/1534] 1910, 'Predigt am 17. April 1533: Der Empfangen ist vom Heiligen geist', WA 37, 53-62.

Luther, M., [1533/1534] 1910, 'Predigt am 25. Dezember 1533: Predigt am Weihnachtstage, Nachmittags', WA 37, 232-238.

Luther, M., [1537] 1911,'Predigten 1537 und Predigtkompilationen (30er Jahre)', WA 45.
Luther, M., [1537] 1926, 'Die Promotions disputation von Palladius und Tilemann', WA 39,1,205-257.

Luther, M., [1538] 1914, 'Enarratio Psalmi LI', WA 40, 2, 313-470.

Luther, M., [1538] 1926, 'Die dritte Disputation gegen die Antinomer, 6. September 1538', WA 39, 1, 486-584.

Luther, M., [1539] 2012, 'Vorrede zum ersten Band der Wittenberger Ausgabe der deutschen Schriften, WA 50,657-661, nuut opgeneem in D. Korsch (Hg.), 2012, Martin Luther: Deutsch-Deutsche Studienausgabe, Band 1: Glaube und Leben, pp. 656-669, Evangelische Verlagsanstalt, Leipzig.

Luther, M., [1545] 2006, 'Vorrede zum ersten Band der lateinischen Schriften der Wittenberger Luther-Ausgabe (1545)', WA 54, 179-187, nuut opgeneem in J. Schilling (Hg.), 2006, Martin Luther: Lateinisch-Deutsche Studienausgabe, Band 2, Christus glaube und Rechtfertigung, pp. 491-509, Evangelischer Verlagsanstalt, Leipzig.

Luther, M., 1883 vv., Weimarer Ausgabe (WA en WA TR), D. Martin Luthers Werke: Kritische Gesamtausgabe, 65 Bände, Böhlaus \& Nachfolger, Weimar.

Schilling, H., 2014, Martin Luther: Rebell in einer Zeit des Umbruchs, Beck, München.

Schilling, J., 2010, 'Aneignungen: Selbstverständnis', in A. Beutel (Hg.), Luther Handbuch, pp. 101-106, Mohr Siebeck, Tübingen.

Schwarz, R., [1986] 2014, Luther, 4. durchgesehene Auflage, Vandenhoeck, Göttingen. (UTB 1926).

Slenczka, N., 2010, 'Christologie', in A. Beutel (Hg.), Luther Handbuch, pp. 381-392, Mohr Siebeck, Tübingen.

Van Wyk, I.W.C., 2001, 'Die "Gemeenskaplike Verklaring oor die Regverdigingsleer" van 30/31 Oktober 1999', Hervormde Teologiese Studies 57(3/4), 835-867. http:// dx.doi.org/10.4102/hts.v57i3/4.1851

Van Wyk, I.W.C., 2011, 'Wat is reformatoriese teologie?: Nadenke na aanleiding van 'n beswaarskrif', HTS Teologiese Studies 67(3), Art. \#1156, 11 pages. http://dx.doi. org/10.4102/hts.v67i3.1156

Zschoch, H., 2010a, 'Aneignungen - Lebenslauf', in A. Beutel (Hg.), Luther Handbuch, pp. 82-91, Mohr Siebeck, Tübingen.

Zschoch, H., 2010b, 'Gattungen - Predigten', in A. Beutel (Hg.), Luther Handbuch, pp. 314-321, Mohr Siebeck, Tübingen. 